\title{
More alike than different: the Spanish and Irish labour markets before and after the crisis
}

\author{
Pablo Agnese ${ }^{1 *}$ and Pablo F Salvador ${ }^{2}$
}

\author{
${ }^{*}$ Correspondence: \\ pablo.agnese@fh-duesseldorf.de \\ ${ }^{1} \mathrm{FH}$ Düsseldorf and IZA, \\ Department of Business Studies, \\ Universität Straße, Gebäude 23.32, \\ 40225 Düsseldorf, Germany \\ Full list of author information is \\ available at the end of the article
}

\begin{abstract}
Spain and Ireland might seem at first to feature very different labour markets, which go from very tight to very flexible labour conditions. Our analysis, however, goes beyond this simplistic argument and brings to light some important similarities. For this purpose, we estimate a dynamic multi-equation structural model for each country and offer two sets of dynamic simulations that account for the swings of the unemployment rates before and after the 2007 crisis. Our results suggest looking beyond the degree of flexibility in both labour markets and focusing instead on other variables usually neglected by more conventional approaches. In particular, such variables as the growth of capital stock, the growth of labour productivity, and demographics, succeed in explaining a great part of the changes in unemployment in both countries.
\end{abstract}

JEL codes: E24, J21, E22, C32

Keywords: Unemployment dynamics, Structural multi-equation models, Chain reaction theory, Simulations, PIGS

\section{Introduction}

The recent crisis of 2007 has left us with more questions than answers. The major economies have seen negative GDP growth rates in 2008 and 2009, just to experience positive rates again in 2010 and 2011. In the European setting, not all member states have been affected in the same way. For example, Germany, the UK, and France are now recovering at a reasonable pace -between 1.5 and 3.5 percent GDP growth rates in 2010 and 2011. The Nordic countries, in turn, yet not as severely hit as in the mid-1990s, seem to have learned from their previous experience and have quickly recovered with GDP growth rates of the order of 3.0 to 5.5 percent in the last two years. On the other hand, much of the discussion now taking place focuses on the less fortunate countries which have come to be known as PIGS (Portugal, Italy, Greece, and Spain, with Ireland joining the club right after the crisis).

The PIGS share a set of similar traits that make for a separate study, to wit: high unemployment rates, persistent fiscal imbalances, weakening financial sectors and credit rationing, severe after-effects of the housing boom, widespread corruption, and frequent strikes. However, a closer look reveals that not all PIGS are the same. For instance, while Greece, Ireland, and Portugal, and more recently Spain, have received financial help from the European Union, Italy has not. Besides, two of these countries -Spain and Irelandunderwent major increases in unemployment, even when compared to the other PIGS.

(C) 2012 Agnese and Salvador; licensee Springer. This is an Open Access article distributed under the terms of the Creative Commons Attribution License (http://creativecommons.org/licenses/by/2.0), which permits unrestricted use, distribution, and reproduction in any medium, provided the original work is properly cited. 
Moreover, the evolution of the unemployment rate in both countries has followed the same pattern in the last decades, although Spain displays much higher rates since the mid-1990s.

Our goal, then, is to study the trajectory of the unemployment rate in Spain and Ireland while highlighting the common drivers for the most part of the past decade and a half. We divide our analysis into two periods, before and after the 2007 crisis, which coincide with the major turning points of the unemployment rate in recent years. We estimate a dynamic labour market model for each country and perform a dynamic accounting exercise to examine how much of the unemployment variation in Spain and Ireland is attributable to the explanatory variables. Our results suggest that the two countries seem to have more similarities than differences -despite the clear contrast in the degree of flexibility of their labour markets.

We base our empirical analysis on the Chain Reaction Theory (CRT) of unemployment. The use of this approach is justified for two reasons. First, its wider methodological perspective permits us to consider non-stationary variables as drivers of the unemployment rate. Second, as shown in Figure 1 (Section 3), the actual rate of unemployment in both countries is far from its equilibrium level, implying that the natural rate of unemployment (NRU) cannot account for the large increases in unemployment.

The paper is structured as follows. Section 2 puts these two economies in context. Section 3 briefly discusses the theoretical framework on which we base our empirical analysis. Section 4 shows the estimated models and the econometric methodology. Section 5 presents the contributions of the exogenous variables to the variation of unemployment, before and after the crisis. And finally, Section 6 concludes.

\section{The two economies in context}

Table 1 shows, for a selected group of countries, the average growth rate of GDP for the last decade and the unemployment rates $(u)$ for 2007 and 2009. ${ }^{1}$ A couple of facts are worth commenting upon. First, Spain and Ireland display average GDP growth rates that are consistently larger than in other parts of the developed world, especially during the years before the 2007 crisis (see the first two rows in Table 1). Second, the drop in these rates from pre to post-2007 averages (see second to third row in Table 1) is important. Not only are these falls more pronounced there than in the major developed economies,
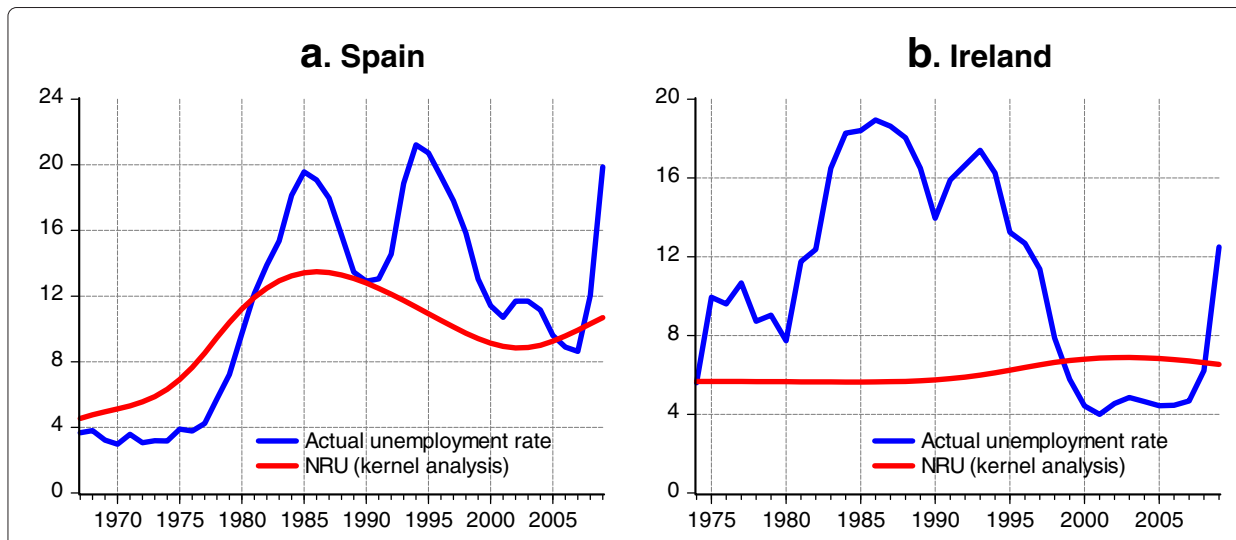

Figure 1 The actual unemployment rate, the NRU, and frictional growth. 
Table 1 Spain and Ireland in a worldwide context

\begin{tabular}{|c|c|c|c|c|c|c|c|c|c|c|c|}
\hline & SPA & IRE & POR & ITA & GRE & EU13 & $\mathrm{DE}$ & $\mathrm{FR}$ & UK & US & JP \\
\hline \multicolumn{12}{|l|}{$\Delta \mathrm{GDP}$} \\
\hline 2000-09 & 2.6 & 3.6 & 0.9 & 0.5 & 3.3 & 1.3 & 0.8 & 1.5 & 1.7 & 1.9 & 0.7 \\
\hline 2000-07 & 3.6 & 5.8 & 1.4 & 1.5 & 4.2 & 2.1 & 1.5 & 2.1 & 2.7 & 2.6 & 1.7 \\
\hline $\begin{array}{c}\text { 2008-09 } \\
\text { u\% }\end{array}$ & -1.4 & -5.2 & -1.3 & -3.3 & 0.01 & -1.8 & -2.0 & -1.1 & -2.3 & -1.0 & -3.3 \\
\hline 2007 & 8.6 & 4.7 & 8.4 & 6.4 & 8.6 & 7.7 & 8.7 & 8.3 & 5.5 & 4.7 & 3.9 \\
\hline 2009 & 19.9 & 12.5 & 10.0 & 8.2 & 9.9 & 9.8 & 7.7 & 9.5 & 7.9 & 9.8 & 5.2 \\
\hline$\Delta$ (p.p.) & 11.3 & 7.8 & 1.6 & 1.8 & 1.3 & 2.1 & -1.0 & 1.2 & 2.4 & 5.1 & 1.3 \\
\hline
\end{tabular}

but they are also different from the ones experienced by similar countries (e.g. the other 'PIGS'). And third, we should highlight the steep rise of both the Spanish and Irish unemployment rates -two and three-fold respectively- which stand out unambiguously from our group of selected countries (last three rows in Table 1).

What we need to understand is why Spain and Ireland are more similar to each other than one is usually led to believe. This is what we do in the following sections, after we briefly discuss the common trends of these two particular economies.

Seemingly, Spain and Ireland have lately evolved in a very similar way (see Table 2 for more details). Both economies witnessed an economic boom in the mid-1990s that lasted until 2007. As a result, falling unemployment rates have characterised this period, ${ }^{2}$ allowing both countries to be counted among those OECD members where employment creation -led mostly by a booming housing market- was most significant (see, for example, Sexton 2002; Walsh 2006; and Bentolila et al. 2010).

Spain and Ireland have also seen the largest migratory inflows among OECD countries in the pre-crisis era. This was motivated, first, by the good performance of these economies and their labour markets and, second, by the different reforms introduced by both governments (see Fitzgerald and Hore 2002; Borjas 2003; Barrett et al. 2002,2006,2011; Carrasco et al. 2008; and González and Ortega 2011).

Despite the similarities, Spain and Ireland differ with respect to the flexibility of their labour markets (Dolado and Jimeno 1997; Fitzgerald and Hore 2002; and Bentolila and

Table 2 Spain and Ireland at a glance

\begin{tabular}{lcc}
\hline Common trends: & Pre-2007 & Post-2007 \\
\hline GDP per capita & rising & falling \\
GDP growth rates & high & low/negative \\
Capital stock growth rates* & low/negative \\
Unemployment & high & rising \\
Employment creation & falling & negative \\
Construction sector (leading sector) & high & job destruction \\
Welfare entitlements* & job creation & rising \\
Migratory flows & falling & out \\
Housing market & in & burst \\
\hline Labour market conditions: $†$ & boom & tight \\
Spain & tight & flexible \\
Ireland & flexible & For see also Additional file 1: Appendix A (Figures i and iii); and for trefer to Figure 1 below.
\end{tabular}

For * see also Additional file 1: Appendix A (Figures i and iii); and for trefer to Figure 1 below. 
Jimeno 2006). Traditionally, Spain has been always characterised by its very rigid labour market (although more flexibility was introduced in the 1990s), while Ireland's labour market has remained flexible for the most part of the last half-century. This has barely changed after the crisis. ${ }^{3}$

The years 2007-2009 deviate from the high macroeconomic and labour market performance experienced by both economies in the preceding years (see Bentolila et al. 2010, and Bergin et al. 2010). Among other things, negative GDP growth rates, rising unemployment (more than two-fold for Spain and almost three-fold for Ireland), and an acute problem in the construction sector which led to massive layoffs, characterise this downtrodden period (see Table 2). Moreover, this coincided with the bursting of the housing bubble and marked the end of the boom times. ${ }^{4}$

\section{A not-so-conventional approach: The Chain Reaction Theory}

We base our empirical analysis on the Chain Reaction Theory (CRT) or prolonged adjustment view of unemployment, initially developed by Karanassou and Snower $(1997,1998)$. As opposed to other more conventional approaches with a focus on equilibrium and the concept of the natural rate of unemployment (NRU), the CRT envisions an actual rate of unemployment that drifts away from its natural counterpart for a prolonged period of time, although not permanently as in the case of the hysteresis hypothesis. According to the NRU, unemployment evolves around an equilibrium rate of unemployment and the labour market spends most of the time at or near this equilibrium rate. At the opposite extreme, the hysteresis hypothesis stresses the path dependency of unemployment and postulates that the equilibrium unemployment rate no longer returns to previous levels after a shock. ${ }^{5}$

The CRT applies dynamic multi-equation systems with spillover effects to explain how unemployment evolves. A main feature of this approach is that the labour market adjusts only slowly to external shocks because many labour market decisions are subject to adjustment costs. Thus, current decisions may depend on past labour market outcomes. These lagged adjustment processes refer, among others, to: (i) employment adjustments arising from labour turnover costs (hiring, training, and firing costs), (ii) wage / price staggering, (iii) insider membership effects, (iv) long-term unemployment effects, and (v) labour force adjustments. ${ }^{6}$

Another striking feature is that, unlike single-unemployment rate models, CRT models can also include trended exogenous variables -imposing here that each growing endogenous variable should be balanced with its set of explanatory variables. In other words, the CRT claims that the time path of unemployment is driven by the interplay between lagged adjustment processes and spillover effects within the labour market. In particular, spillover effects arise when shocks to a specific equation feed through the system, while the label "shock" refers to changes in the exogenous variables.

The workings of the CRT can be represented with a simple model of the labour market:

$$
\begin{aligned}
n_{t} & =\alpha_{1} n_{t-1}+\beta_{1} k_{t}-\gamma_{1} w_{t} \\
w_{t} & =\alpha_{2} w_{t-1}+\beta_{2} x_{t}-\gamma_{2} u_{t} \\
l_{t} & =\alpha_{3} l_{t-1}+\beta_{3} z_{t}+\gamma_{3} w_{t}
\end{aligned}
$$

where $n_{t}, w_{t}$, and $l_{t}$ denote employment, real wage, and labour force, respectively; $k_{t}$ is real capital stock, $x_{t}$ represents a wage-push factor, and $z_{t}$ is working-age population; 
the $\beta$ 's and $\gamma$ 's are positive constants. ${ }^{7}$ The autoregressive parameters $\alpha_{1}, \alpha_{2}$ and $\alpha_{3}$ are positive and less than unity and represent the employment adjustment, wage/price staggering effects, and labour force adjustment, respectively. All variables are in logs and we ignore the error terms for ease of exposition. The unemployment rate (not in logs) can be approximated by:

$$
u_{t} \simeq l_{t}-n_{t}
$$

We refer to the lags of the endogenous variables in the labour market model as the "lagged adjustment processes". Furthermore, the $\gamma$ 's generate spillover effects, since changes in an exogenous variable -say the capital stock- can also affect the real wage and labour supply equations. Thus, in the presence of spillover effects, the short-run elasticities of the dependent variables to the exogenous ones are no longer captured by the $\beta$ 's. In other words, when $\gamma$ is zero labour market shocks do not spillover from labour supply to labour demand and vice versa, and the influence of the exogenous variables $\left(k_{t}\right.$ and $z_{t}$ ) on unemployment can be measured through individual analysis of the labour demand and supply equations.

Another point that can be made for using the CRT lies in its disequilibrium nature, something that, as will become clear soon, proves most suitable for Spain and Ireland. This situation can be illustrated by way of this simple relationship:

$$
u_{t}^{L R}=N R U+\theta
$$

where the long-run unemployment rate $u_{t}^{L R}$ is equal to the NRU plus an additional term $\theta$ accounting for frictional growth-that is, the outcome of interactions between labour market adjustment processes and shocks which are embedded in the non-stationary variables of the model.

According to the CRT, the swings of the unemployment rate should then be explained by something other than shocks and institutions -as is the case of most NRU-based models (see, most representatively, Gordon 1997, and Blanchard and Wolfers 2002). As a result, under the CRT we should be able to distinguish an actual rate of unemployment that is fairly independent of the NRU -the NRU being no longer an "attractor" of the actual rate. As per Figure 1 below, this seems to be the case for both the Spanish and Irish labour markets.

To come up with both NRU series we rely on kernel density analysis, yet we avoid presenting the whole methodological aspects for reasons of space. ${ }^{8}$ Simply put, the idea behind the kernel analysis is to identify, given our sample periods, the permanent from the temporary components of all the exogenous variables involved in (1)-(3), and use the former to compute the NRU series according to the definition in (4).

Three facts are drawn from Figure 1 that deserve our attention. First, the conventional approach to labour markets seems to be at odds with the experience in both countries. Indeed, the actual rate of unemployment is far from its equilibrium level, implying a high degree of frictional growth and, consequently, that the NRU cannot account for the large increases in unemployment. As seen in the figure, this is especially true for Spain during the mid-1980s and 1990s and for Ireland in most of the pre-2000s period.

Second, it is well substantiated in the literature that Spain has a much more rigid labour market than Ireland, something that is clearly seen from the higher levels displayed by the Spanish NRU throughout the samples. In particular, the pattern of the Spanish NRU 
shows a significant upturn during the 1980s due to the enlargement of the welfare state, and an important (yet less drastic) downturn in the 1990s which came as a result of the liberalisation process then undergone by the country. This process was later reversed in subsequent years with the change of the administration. On the other hand, the pattern of Ireland's NRU shows only a slight increase in the 2000s after the introduction of measures such as the minimum wage law.

Third and last, as a cautionary note, it should be noticed that our calculations of the NRU series are based on our proposed models for each country, which are shown in the next section. Even though the patterns of both series are similar to others found in the literature, by no means should they be taken as the final word in the NRU calculations for these two countries. In spite of this, we believe that our use of the CRT is more than justified for its wider methodological perspective, which permits us to consider non-stationary variables as drivers of the unemployment rate.

\section{Two macro labour models}

\subsection{Data and methodology}

The dataset is obtained from the OECD Economic Outlook and the sample period of our analysis is 1967-2009 for Spain and 1974-2009 for Ireland. Table 3 gives the definitions of the variables included in the selected equations. ${ }^{9}$

The estimation strategy involves the Autoregressive Distributed Lagged (ARDL) approach developed by Pesaran (1997), Pesaran and Shin (1999), and Pesaran et al. (2001). The justification of this choice can be summarised as follows. It has been shown that the ARDL yields consistent estimates both in the short- and long-run, and can be reliably used in small samples for hypothesis testing irrespective of whether the regressors are $\mathrm{I}(1)$ or $\mathrm{I}(0)$. Therefore, the ARDL offers an alternative that avoids the pretesting problem implicit in other popular cointegration techniques -the Johansen maximum likelihood, and the Phillips-Hansen semi-parametric, fully-modified OLS procedures. Furthermore, Pesaran and Shin (1999) argue that the Phillips-Hansen and ARDL approaches are directly comparable, and the estimator of the former is outperformed by the ARDL estimator, especially when the sample size is relatively small (as in our case).

Our dynamic labour market model comprises labour demand, wage setting, and labour supply equations: ${ }^{10}$

$$
\mathbf{A}_{0} \mathbf{y}_{t}=\sum_{i=1}^{2} \mathbf{A}_{i} \mathbf{y}_{t-i}+\sum_{i=0}^{2} \mathbf{D}_{i} \mathbf{x}_{t-i}+\varepsilon_{t}
$$

Table 3 Definitions of variables

\begin{tabular}{|c|c|c|c|}
\hline$n$ & total employment (log) & $c$ & private consumption (\% of GDP) \\
\hline 1 & total labour force (log) & $f d$ & exports-imports (\% of GDP) \\
\hline w & real compensation per employee (log) & $b$ & social security benefits ( $\%$ of GDP) \\
\hline \multirow[t]{2}{*}{$u$} & unemployment rate $(\simeq I-n)$ & $\tau^{i}$ & indirect taxes (\% of GDP) \\
\hline & & po & total population (log) \\
\hline k & real capital stock (log) & z & participation rate $\left(\frac{\text { labour force }}{\text { working-age pop. }}\right)$ \\
\hline pr & real labour productivity (log) & $d^{96}$ & dummy (1 in 1996-2008; 0 other) \\
\hline$r$ & real long-term interest rate & $d^{00}$ & dummy (1 in 2000-2008; 0 other) \\
\hline
\end{tabular}


where $\mathbf{y}_{t}$ is a vector of endogenous variables (employment, real wage, and labour force), $\mathbf{x}_{t}$ is a vector of exogenous variables, the $\mathbf{A}_{i}$ 's and $\mathbf{D}_{i}$ 's are coefficient matrices, and $\varepsilon_{t}$ is a vector of strict white noise error terms.

Each equation of the labour market system (6) is estimated following the ARDL approach and the selected specifications pass a battery of diagnostic tests for serial correlation, linearity, normality, heteroskedasticity and autoregressive conditional heteroskedasticity, and structural stability. Finally, to account for potential endogeneity and cross-equation correlation we estimate the labour market model for each country with 3SLS. These estimated equations, together with the definition in (4), are then used to obtain the "reduced form" unemployment rate equation underlying the rest of our empirical analysis.

In what follows we discuss our estimation results and provide an overall evaluation of the selected labour market models. ${ }^{11}$

\subsection{Estimated models}

\subsubsection{Labour demand}

Table 4 shows the 3SLS estimates of the employment equation for Spain and Ireland. Both countries display a high degree of employment persistence. The coefficient is lower in Spain, 0.62, than in Ireland, 0.78, indicating a quicker speed of adjustment to economic disturbances in the former country. Karanassou and Sala (2009) find a similar level of employment persistence for the Spanish labour demand, 0.66. In the study of Benito and Hernando (2008) this coefficient ranges between 0.77 and 0.86; in Bande and Karanassou (2009 and 2010) employment persistence is somewhat smaller, 0.52. In the case of Ireland, employment persistence is in the range of Görg et al. (2009) -between 0.68 and 0.77 .

These results may be at first surprising, given the known flexibility of the Irish labour market. ${ }^{12}$ Spain is characterised by very rigid labour market laws that make the Spanish labour market quite inflexible, although more flexibility has been introduced in the 1990s

Table 4 Labour demand equations, 3SLS

\begin{tabular}{|c|c|c|c|}
\hline \multicolumn{4}{|c|}{ Dependent variable: $n_{t}$} \\
\hline & coefficient & & coefficient \\
\hline cnt. & $2.27[0.000]$ & cnt. & $1.19[0.010]$ \\
\hline$n_{t-1}$ & $0.62[0.000]$ & $n_{t-1}$ & $0.78[0.000]$ \\
\hline$\Delta n_{t-1}$ & $0.28[0.016]$ & & \\
\hline$w_{t}$ & $-0.40[0.000]$ & $w_{t}$ & $-0.12[0.101]$ \\
\hline$k_{t}$ & $0.26[0.000]$ & $k_{t}$ & $0.13[0.020]$ \\
\hline \multirow[t]{3}{*}{$\Delta k_{t}$} & $1.70[0.000]$ & $\Delta k_{t}$ & $1.53[0.000]$ \\
\hline & & $\Delta k_{t-1}$ & $-0.76[0.001]$ \\
\hline & & $\tau^{i}$ & $-0.78[0.010]$ \\
\hline$c_{t}$ & $1.35[0.000]$ & & \\
\hline$f d_{t}$ & $0.69[0.000]$ & & \\
\hline$\Delta f d_{t}$ & $-0.48[0.005]$ & & \\
\hline $\bar{r}^{2}$ & 0.997 & & 0.996 \\
\hline s.e. & 0.010 & & 0.014 \\
\hline LL & 143.01 & & 105.70 \\
\hline
\end{tabular}

Note: $p$-values in brackets; $\Delta$ is the difference operator; $\vec{r}^{2}$ the adjusted $r$-squared; s.e. the standard error of regression; and $L L$ the log likelihood. 
(see, for example, Dolado and Jimeno 1997; Fitzgerald and Hore 2002; and Bentolila and Jimeno 2006).

The effect of capital stock is significant in both economies, with a long-run elasticity of 0.68 in Spain (e.g. a $1 \%$ rise in $k$ boosts employment by $0.68 \%$ ) and 0.6 in Ireland. Karanassou and Sala (2009) and Bande and Karanassou (2009 and 2010) find similar results for Spain. In the former study, the authors restrict the long-run impact of capital stock to unity, whereas in the latter two, this impact is 0.52. According to Benito and Hernando (2008), the long-run impact of capital stock on the Spanish labour demand lies between 0.55 and 0.65 . In the Irish case, capital stock is significant in the studies of Fitzgerald and Hore (2002) and Bergin et al. (2010).

Employment is also sensitive to wage variations -with a long-run elasticity close to negative unity in Spain and -0.54 in Ireland. According to Karanassou and Sala (2009), real wages impact the Spanish labour demand with a negative unit elasticity in the longrun, while this impact falls to -0.67 in Bande and Karanassou (2009 and 2010). Benito and Hernando (2008) find a lower long-run wage elasticity, -0.37 , while in the study of Bentolila and Saint-Paul (1992) this value is -1.86, yet the authors consider it to be quite high relative to previous studies. According to Görg et al. (2009) the long-run impact of wages on the Irish labour demand lies between -0.19 and -0.31 . Wages are also significant in the studies of Barrett et al. (2006) and Barrett and Bergin (2009).

Besides the common determinants we have also identified other idiosyncratic influences: private consumption and foreign demand in Spain, and indirect taxes in Ireland. Karanassou and Sala (2009) find these same idiosyncratic variables in the case of Spain, whereas indirect taxes exert an important influence on the Irish labour market according to Decoster et al. (2009).

\subsubsection{Wage-setting}

Table 5 presents the estimates of the real wage equation for the two countries. The quicker adjustment takes place in Ireland now, where the inertia coefficient is 0.65 , compared to the more sluggish response in Spain, 0.76. The latter coefficient is in line with the studies of Bande and Karanassou (2009 and 2010), and higher than the one found in Karanassou and Sala (2009 and 2010).

Table 5 Wage-setting equations, 3SLS

\begin{tabular}{lrrr}
\hline $\begin{array}{l}\text { Dependent variable: } \boldsymbol{w}_{\boldsymbol{t}} \\
\text { Spain, 1967-2009: }\end{array}$ & Ireland, 1974-2009: \\
\hline \multicolumn{1}{c}{ coefficient } & & coefficient \\
$c n t$. & $0.67[0.019]$ & $c n t$. & $1.97[0.000]$ \\
$w_{t-1}$ & $0.76[0.000]$ & $w_{t-1}$ & $0.65[0.000]$ \\
$\Delta w_{t-1}$ & $0.29[0.020]$ & $\Delta w_{t-2}$ & $-0.42[0.000]$ \\
$u_{t}$ & $-0.42[0.000]$ & $u_{t}$ & $-0.21[0.010]$ \\
$p r_{t}$ & $0.16[0.006]$ & $p r_{t}$ & $0.15[0.003]$ \\
$b_{t}$ & $0.97[0.003]$ & $b_{t}$ & $0.57[0.030]$ \\
$d_{t}^{00}$ & $-0.03[0.001]$ & $d_{t}^{96}$ & $-0.02[0.070]$ \\
\hline $\bar{r}^{2}$ & 0.996 & & 0.990 \\
s.e. & 0.013 & & 0.017 \\
$L L$ & 130.31 & & 100.41 \\
\hline
\end{tabular}

Note: $p$-values in brackets; $\Delta$ is the difference operator; $r^{2}$ the adjusted r-squared; s.e. the standard error of regression; and $L L$ the log likelihood. 
Further, the wage equation has the same determinants in both countries. Real wages are influenced by unemployment, labour productivity, unemployment benefits, and a dummy variable that considers the important influence of immigration in the last years. ${ }^{13}$ The long-run elasticities of real wages to labour productivity are 0.67 for Spain and 0.43 for Ireland.

All variables, except for immigration, are also important determinants of the Spanish wage formation in the works by Karanassou and Sala (2009 and 2010) and in the studies of Bande and Karanassou (2009 and 2010) and Bande et al. (2008). There, the long-run elasticity of real wages with respect to productivity ranges between 0.52 and 0.85 . According to Fitzgerald and Hore (2002), unemployment, labour productivity, and immigration determine both the Irish and Spanish wage setting equations. The negative impact of immigration on Irish wage setting is well documented in the works by Borjas (2003) and Barrett et al. (2002, 2006 and 2011), while Carrasco et al. (2008) examine this impact on Spanish wages.

\subsubsection{Labour force}

Table 6 shows the two labour supply equations. Here the labour supply in Spain features the higher persistence. Note also that, in Ireland, the persistence in labour supply decisions does not differ substantially from that of the wage setting, 0.6. As in Karanassou and Sala (2009), the Spanish labour supply shows the highest persistence of the three estimated equations, $0.92 .^{14}$

The role of wages and unemployment in the labour supply decisions of the two countries is as expected. Wages exert an overall positive influence with a long-run impact of 0.5 in Spain and 0.32 in Ireland, while unemployment has a negative effect -in Spain via a discouraged workers effect and in Ireland through the level of unemployment (see Leschke and Watt 2010). According to Karanassou and Sala (2009), wages influence labour supply decisions with a 0.43 long run elasticity and the effect of unemployment is also measured through the discouraged worker effect. However, Bande and Karanassou

Table 6 Labour force equations, 3SLS

\begin{tabular}{|c|c|c|c|}
\hline \multicolumn{4}{|c|}{ Dependent variable: $I_{t}$} \\
\hline \multicolumn{2}{|c|}{ Spain, 1967-2009: } & \multicolumn{2}{|c|}{ Ireland, 1974-2009: } \\
\hline & coefficient & & coefficient \\
\hline cnt. & $0.71 \quad[0.112]$ & cnt. & $-2.20[0.096]$ \\
\hline \multirow{2}{*}{$I_{t-1}$} & $0.92[0.000]$ & $I_{t-1}$ & $0.60[0.000]$ \\
\hline & & $\Delta I_{t-2}$ & $0.21 \quad[0.104]$ \\
\hline$w_{t}$ & $0.04 \quad[0.053]$ & $w_{t}$ & $0.13[0.001]$ \\
\hline$\Delta w$ & $-0.13[0.061]$ & & \\
\hline \multirow[t]{2}{*}{$z_{t}$} & $0.32[0.009]$ & pot & $0.43[0.012]$ \\
\hline & & $u_{t}$ & $-0.27 \quad[0.001]$ \\
\hline$\Delta u$ & $-0.25 \quad[0.000]$ & $\Delta u_{t}$ & $0.28[0.012]$ \\
\hline$r_{t}$ & $0.14[0.000]$ & & \\
\hline$d_{t}^{00}$ & $0.01[0.026]$ & $d_{t}^{96}$ & $0.03[0.000]$ \\
\hline$\overline{\bar{r}^{2}}$ & 0.999 & & 0.996 \\
\hline s.e. & 0.007 & & 0.012 \\
\hline$L L$ & 159.12 & & 113.71 \\
\hline
\end{tabular}

Note: $p$-values in brackets; $\Delta$ is the difference operator; $\vec{r}^{2}$ the adjusted $r$-squared; s.e. the standard error of regression; and $L L$ the log likelihood. 
(2009 and 2010) find a smaller impact of wages on the labour supply. In the case of Ireland, wages play an important role in the works of Barrett and Bergin (2009) and Bergin et al. (2010).

It is through the participation rate and total population, respectively, that we capture demographic influences on the labour supply movements in Spain and Ireland. Population is an important determinant affecting the Irish labour supply according to Barrett et al. (2006), Barrett and Bergin (2009), and Bergin et al. (2010).

In Spain, labour supply decisions are also found to be dependent on the ups and downs of the interest rate. This is not surprising, given the high level of indebtedness of the Spanish families that were caught up by the housing bubble in recent years. What is more, spiralling increases in house prices have been combined with increases in home ownership (see Garriga 2010), making the situation the more unbearable in terms of mortgage obligations. Recent increases in the interest rate will definitely force those under financial stress to participate in the labour market more eagerly.

Finally, we measure the significant impact of immigration in both labour markets by including a positive and significant dummy variable. Fitzgerald and Hore (2002) and Barrett et al. (2006) find a significant impact of immigration on the Irish labour supply, while Karanassou and Sala (2009) and Palma and Martín (2010) show this impact for Spain.

\subsection{Evaluation of the models}

\subsubsection{Fitted values and diagnostic tests}

Here we check the models' ability to replicate the actual patterns of the unemployment rates. As Figure 2 shows, the estimated labour market models manage to track the actual patterns at a very close range in the two countries. This is so in spite of having estimated the unemployment rates while making use of a model of equations and not a single-equation model. Do observe that the fit is slightly better for Spain. ${ }^{15}$

Table 7 shows the misspecification and stability tests for both systems of equations. Selected misspecification tests are: heteroskedasticity (HET) and conditional heteroskedasticity $(A R C H)$ tests; Lagrange multiplier test for serial correlation $(S C)$; Ramsey's linearity test $(L I N)$; and Jarque-Bera test for normality $(N O R)$. All tests are distributed as $\chi^{2}(1)$ with the exception of the Jarque-Bera test, which is distributed as a $\chi^{2}(2)$. Selected stability tests are the Cusum and Cusum ${ }^{2}$, which ensure that the

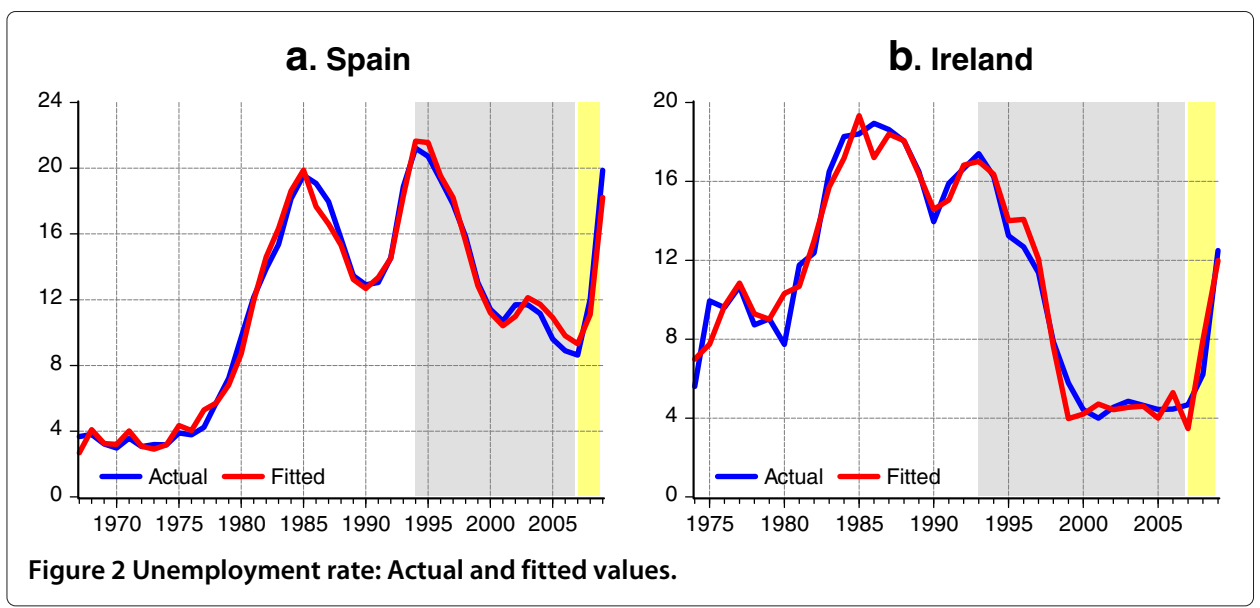


Table 7 Diagnostic tests

\begin{tabular}{|c|c|c|c|}
\hline Spain: & $L D$ & WS & $L F$ \\
\hline \multicolumn{4}{|c|}{ Misspecification tests } \\
\hline $\operatorname{SC}\left[\chi^{2}(1)\right]$ & $3.11[0.078]$ & $0.02[0.902]$ & $0.97[0.325]$ \\
\hline $\operatorname{LIN}\left[\chi^{2}(1)\right]$ & $0.28[0.599]$ & $5.37[0.021]$ & $0.51[0.474]$ \\
\hline $\operatorname{NOR}\left[\chi^{2}(2)\right]$ & $1.66[0.436]$ & $1.97[0.373]$ & $3.89[0.143]$ \\
\hline $\operatorname{HET}\left[\chi^{2}(1)\right]$ & $0.40[0.530]$ & $4.12[0.042]$ & $2.20[0.138]$ \\
\hline $\mathrm{ARCH}\left[\chi^{2}(1)\right]$ & $0.92[0.338]$ & $1.14[0.285]$ & $0.00[0.992]$ \\
\hline \multicolumn{4}{|c|}{ Stability tests ( $5 \%$ signif.) } \\
\hline Cusum & $\checkmark$ & $\checkmark$ & $\checkmark$ \\
\hline Cusum $^{2}$ & $\checkmark$ & $\checkmark$ & $\checkmark$ \\
\hline Ireland: & $L D$ & WS & $L F$ \\
\hline \multicolumn{4}{|c|}{ Misspecification tests } \\
\hline $\operatorname{SC}\left[\chi^{2}(1)\right]$ & $0.57[0.451]$ & $0.16[0.688]$ & $1.20[0.273]$ \\
\hline $\operatorname{LIN}\left[\chi^{2}(1)\right]$ & $2.67[0.102]$ & $1.99[0.158]$ & $0.25[0.617]$ \\
\hline $\operatorname{NOR}\left[\chi^{2}(2)\right]$ & $0.74[0.690]$ & $4.34[0.114]$ & $0.23[0.893]$ \\
\hline $\operatorname{HET}\left[\chi^{2}(1)\right]$ & $0.00[0.999]$ & $0.30[0.587]$ & $0.01[0.930]$ \\
\hline $\mathrm{ARCH}\left[\chi^{2}(1)\right]$ & $0.57[0.451]$ & $1.03[0.310]$ & $0.11[0.746]$ \\
\hline \multicolumn{4}{|c|}{ Stability tests ( $5 \%$ signif.) } \\
\hline Cusum & $\checkmark$ & $\checkmark$ & $\checkmark$ \\
\hline Cusum $^{2}$ & $\checkmark$ & $\checkmark$ & $\checkmark$ \\
\hline
\end{tabular}

estimated equations are structurally stable. As seen from Table 7, almost all equations pass the tests easily. Remember that the best specifications for the equations were selected on the basis of the standard selection criteria (Akaike Information Criterion and Schwarz Bayesian Criterion). For each country, these equations were then re-estimated as a system by the three-stage least squares method (3SLS), so as to address the endogeneity and cross-equation correlation problems.

\subsubsection{The ARDL approach and the Johansen method}

To further check the validity of the estimated models we perform a second control. We want to test whether the long-run relationships implied by our estimations are statistically no different from those obtained by Johansen's method. The Johansen method for cointegration outperforms other conventional techniques (e.g. Engle-Granger) in that it allows for a complete identification of the number of cointegrating vectors. In general, for a given number of growing variables $n$ we can only expect to have up to $n-1$ long-run relationships. ${ }^{16}$ Therefore, by relying on Johansen's method whenever $n>2$, we avoid assuming the existence of a unique cointegrating vector $(\mathrm{CV})$ when there are actually more than one. In other words, while Johansen's multivariate method can deliver all possible cointegrating vectors $r$, other single-equation methods (like Engle-Granger) would only produce a linear combination of all those long-run relationships.

For all three equations in each of our two models we estimate a VAR featuring the same variables, lag order, and sample period, as those used before in the ARDL approach. In order to determine the number of cointegrating vectors $r$ Johansen (1988) proposes two likelihood ratio (LR) tests-trace and maximum eigenvalues. In turn, the optimal model selection for the VARs in relation with the deterministic components (e.g. intercepts or trends, both restricted and unrestricted, or any possible combination) is done by following the Pantula principle. The Pantula principle (Johansen 1992; Pantula 1989) 
involves estimating a series of VARs specifications while moving from the most restrictive to the least restrictive of them (Johansen 1995). This would enable us to select the correct deterministic specification and the order of the cointegration rank.

The results of this analysis are summarised in Table 8, which compares the CVs resulting from our previous ARDL estimations and the Johansen method. A LR test, distributed as a $\chi^{2}(q)$-with $q$ the number of restrictions -restricts Johansen's CVs to the corresponding long-run ARDL values. On the last column we can see that none of the restrictions can be rejected at conventional critical values, indicating cointegration among the growing variables of each equation. Finally, notice that each of the ARDL equations can be reparameterised into an ECM; this provides a further indication of cointegration since the error correction term turns out negative and significant in all cases (first column).

\section{Counterfactual experiments: How different, how similar?}

We use the estimated systems of Section 4.2 to perform a dynamic accounting exercise and examine how much of the unemployment variation in Spain and Ireland is attributable to the explanatory variables. We evaluate both the common variables -capital stock, labour productivity, unemployment benefits and demographics- and those that are not.

We consider two periods, before and after the recent crisis of 2007, stretching between the major turning points of the unemployment rate in recent years. The first turning points are 1994 for Spain and 1993 for Ireland, when unemployment started a downward trend in both countries that stabilised between 2005 and 2007 (this is our pre-2007 analysis). This period coincides with the extraordinary economic performance of both economies (see, for example, Bentolila et al. 2010, for Spain and Barrett et al. 2011 for Ireland). Unemployment rates then started to rise abruptly in both countries during 2007, ${ }^{17}$ thus making for our second period of analysis (or post-2007 analysis).

Table 8 Validity of the long-run relationships

\begin{tabular}{|c|c|c|c|c|}
\hline \multicolumn{2}{|c|}{ ARDL } & \multicolumn{2}{|r|}{ Johansen } & \multirow[t]{2}{*}{ LR test } \\
\hline$e c m_{t-1}$ & $C V$ & $r$ & $C V$ & \\
\hline$[L D]$ & $(n w k)$ & & $(n w k)$ & \\
\hline \multicolumn{5}{|l|}{ Spain: } \\
\hline$-0.34(0.000)$ & $\left(\begin{array}{lll}1 & -1.06 & 0.69\end{array}\right)$ & 2 & $\left(\begin{array}{lll}1 & -1.20 & 0.80\end{array}\right)$ & $\chi^{2}(2)=3.52[0.172]$ \\
\hline \multicolumn{5}{|l|}{ Ireland: } \\
\hline$-0.20(0.029)$ & $\left(\begin{array}{lll}1 & -0.62 & 0.65\end{array}\right)$ & 2 & $\left(\begin{array}{lll}1 & -0.59 & 0.61\end{array}\right)$ & $\chi^{2}(1)=1.63[0.201]$ \\
\hline \multicolumn{5}{|l|}{$[W S]$} \\
\hline \multicolumn{5}{|l|}{ Spain: } \\
\hline$-0.22(0.000)$ & $\left(\begin{array}{ll}1 & 0.66\end{array}\right)$ & 1 & $\left(\begin{array}{ll}1 & 2.89\end{array}\right)$ & $\chi^{2}(1)=0.50[0.480]$ \\
\hline \multicolumn{5}{|l|}{ Ireland: } \\
\hline$-0.32(0.003)$ & $\left(\begin{array}{ll}1 & 0.41\end{array}\right)$ & 1 & $\left(\begin{array}{ll}1 & 0.35\end{array}\right)$ & $\chi^{2}(1)=2.67[0.125]$ \\
\hline \\
\hline \multicolumn{5}{|l|}{ Spain: } \\
\hline$-0.09(0.074)$ & $\left(\begin{array}{ll}1 & 0.44\end{array}\right)$ & 1 & $\left(\begin{array}{ll}1 & 0.68\end{array}\right)$ & $\chi^{2}(2)=4.30[0.116]$ \\
\hline \multicolumn{5}{|l|}{ Ireland: } \\
\hline$-0.34(0.006)$ & $\left(\begin{array}{lll}1 & 0.31 & 1.09\end{array}\right)$ & 1 & $\left(\begin{array}{lll}1 & 2.85 & 0.40\end{array}\right)$ & $\chi^{2}(2)=0.24[0.889]$ \\
\hline
\end{tabular}

Notes: $C V$ = cointegrating vector; $r=$ number of $C V s$; $p$-values in parentheses; moreover, $L D$ is labour demand, WS is wage-setting, and $L F$ is labour force; $5 \%$ critical values for the LR test are: $\chi^{2}(1)=3.84 ; \chi^{2}(2)=5.99$ 
The methodology underlying the CRT has been widely used in several places in the literature to see how much of the changes in the unemployment rate can be explained by changes in the exogenous variables of the model. ${ }^{18}$ For each of the models the procedure goes as follows. First, we set all the explanatory variables simultaneously to certain year and create a new (virtual) path of the unemployment rate. Then we compare both trajectories to see the joint contribution to the changes in unemployment. Next we assess the impact of the exogenous variables individually by fixing each of them to the same year as before, thus creating the virtual path of the unemployment rate over the specific period. Finally, we once again contrast the actual and simulated unemployment series -the difference being now the dynamic contribution of each exogenous variable.

\subsection{Pre-2007 analysis}

We begin the analysis by focusing on the years before the crisis of 2007, where both economies were faced with a prospective future. Figure 3 illustrates the actual and simulated trajectories (for all variables taken together) of the unemployment rates of Spain (1994-2007) and Ireland (1993-2007) during the period that preceded the global meltdown.

Notice the similitudes between Figures 3a and 3b: (i) the actual rates of unemployment (blue lines) went sharply down in both countries (from 21.2 to 8.6 percent in Spain and from 17.4 to 4.7 percent in Ireland); and (ii) the simulated ones (red lines) remained almost unaltered, implying that for both models all the exogenous variables explain the whole of the change in unemployment. That is, both unemployment rates would have remained nearly the same had all the exogenous variables been kept fixed at their original values.

This golden era of unparalleled high performance is very well documented. ${ }^{19}$ In particular for the interlude years of 2005-2007 in Spain, a one-digit unemployment rate can be observed for the very first time in the country's short democratic history -which succeeded Franco's dictatorship (1939-1975) and the so-called transition years (1976-1982). Ireland, on the other side, which enjoyed a much freer hand on economic matters than Spain -especially after her recognition by Britain through the Ireland Act of 1949-, came to be known as the Celtic tiger (see Walsh 2006, and Barrett and Bergin, 2009). This
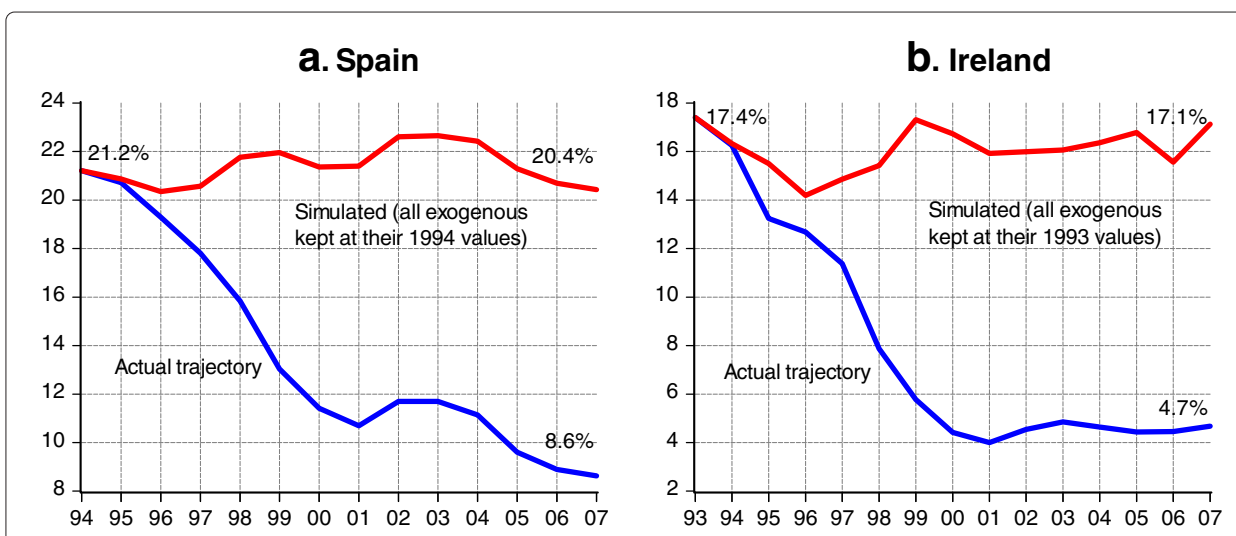

Figure 3 Unemployment rate: Joint dynamic contributions, pre-2007. 
is in allusion to the great economic expansion experienced during 1995-2007, which reminisces that of the East Asian tigers a few decades earlier.

To see both the differences and similitudes of both countries' experiences we need to delve deeper. For this, let us first review all the exogenous variables that are common to both systems of equations. For the ease of presentation we also group the variables into: growth (capital and labour productivity), welfare (social security benefits), demographics (participation rates, population, and a dummy variable for immigration), and other (those variables which are not common).

Figure 3 can be further broken down into the individual contributions of each exogenous variable. This is what we do in Table 9 for the two models. There, it can be seen how all variables changed in the pre-2007 period $(\Delta)$ (see also Additional file 1: Appendix A). Notice on the first row that both unemployment rates went down on approximately the same absolute value (around 13 percentage points). Next to the changes in the variables we can read the individual contribution of each particular variable to the change in the unemployment rate $(\Delta u)$ and, to the end of the table, the sum of all contributions -or what is nearly the same, the joint contribution. In addition, in the bottom -side of the table we arrange the contributions by groups- as defined in the previous paragraph.

The first striking feature arising from the table is the notorious contribution of capital accumulation to the fall of the unemployment rates. For Ireland, in particular, this individual contribution more than doubled that of Spain in absolute values: -24.1 and 9.2 percentage points, respectively. ${ }^{20}$ Along this contribution we should mention that of labour productivity. As can be seen from our systems of equations in Section 4, labour productivity is only entertained in the wage-setting equation. ${ }^{21}$ Therefore, its contribution in terms of unemployment should be understood as the result of productivityled wage effects (e.g. higher wages leading to higher unemployment). This means that, for our simulations, labour productivity and unemployment always move in the same direction. ${ }^{22}$

Table 9 Changes in variables and contributions, pre-2007

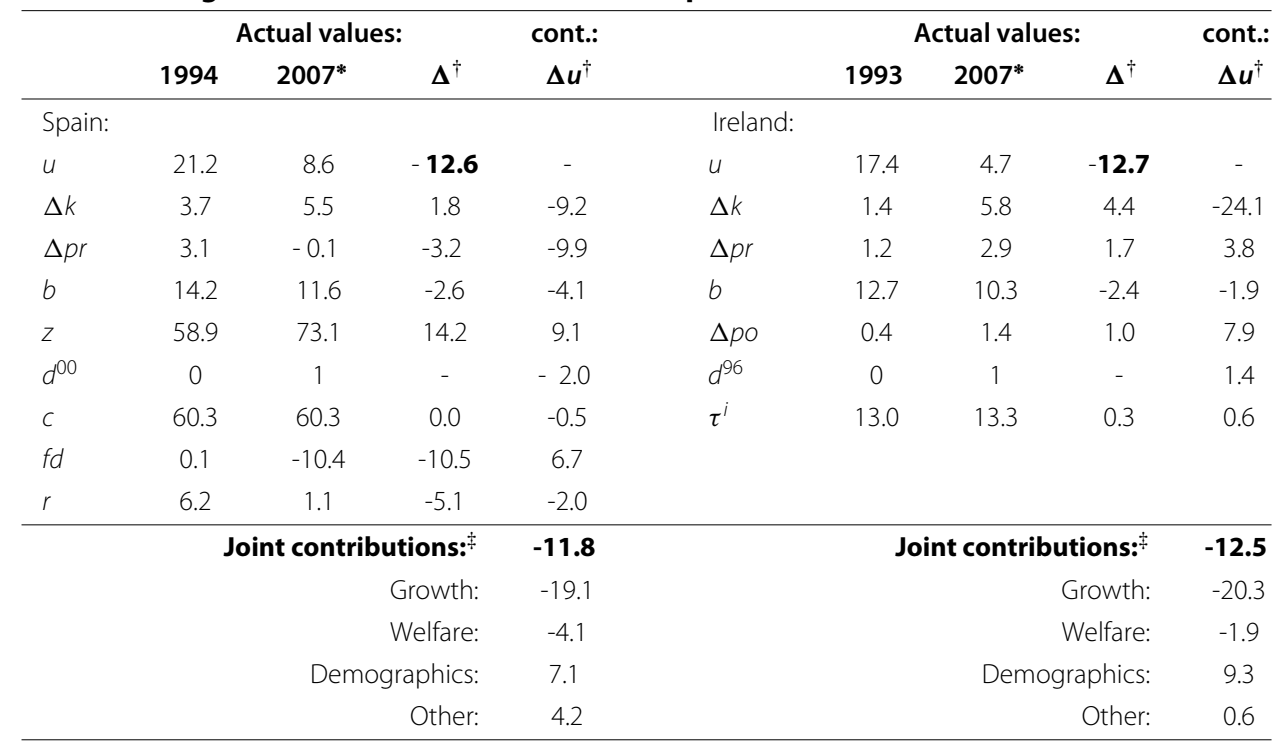

${ }^{*}$ : For differences $(\Delta k, \Delta p r, \Delta p o)$, avg. growth in 1993/4-2007; ${ }^{\dagger}:$ in percentage points; ${ }^{*}$ : Also, approximately the sum of all individual contributions. 
For Spain, the productivity-led fall in real wages results in a contribution of -9.9 percentage points, while for Ireland, the productivity-led increase in real wages determines a 3.8 percentage points contribution to unemployment. When we group these two contributions though, the differences disappear (see the row labelled as 'Growth' at the bottom of Table 9).

As seen more clearly in Figure 4, the contributions of the capital stock were very significant in both cases but noticeably larger in Ireland (Figures 4a and 4b). Moreover, labour productivity went in opposing directions in Spain and Ireland and so did the contributions to unemployment. However, the contribution for Spain was more than twice that for Ireland (Figures 4c and 4d). Despite the differences, the net contribution of the growth variables turns out to be quite similar in both countries (Figures $4 \mathrm{e}$ and $4 \mathrm{f}$ ).
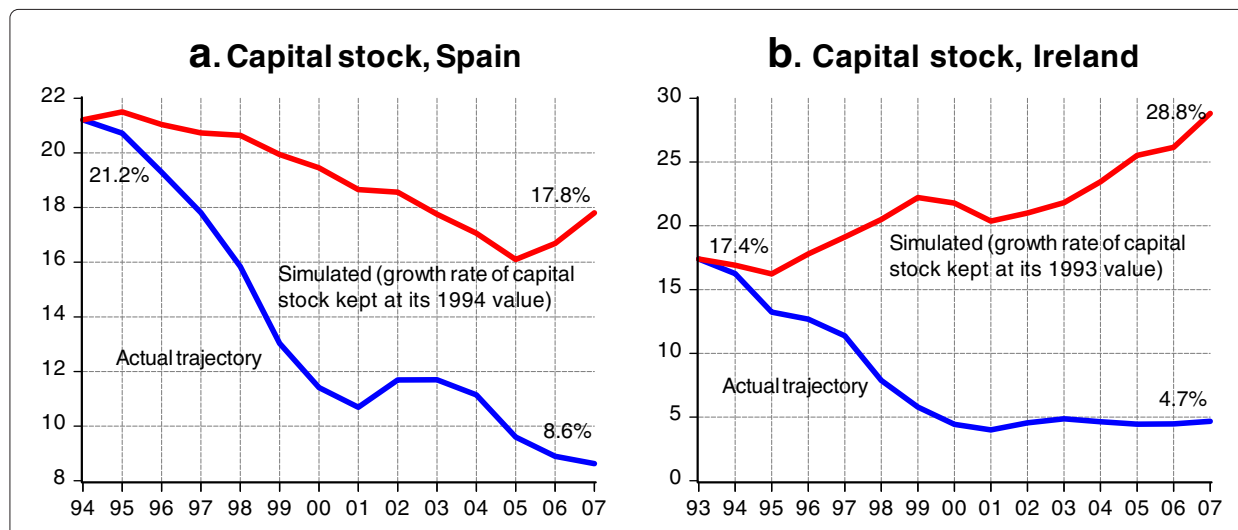

\section{Labour productivity, Spain}

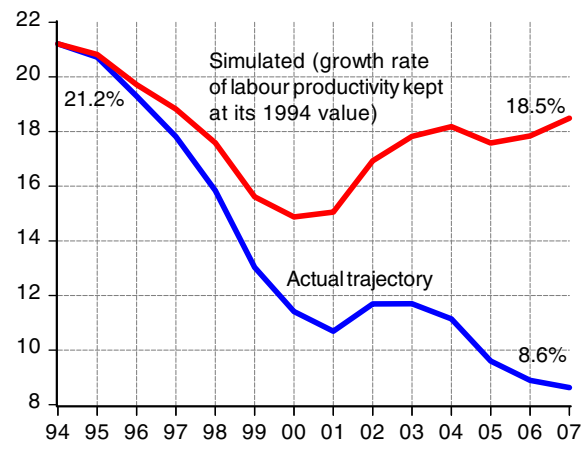

\section{d. Labour productivity, Ireland}

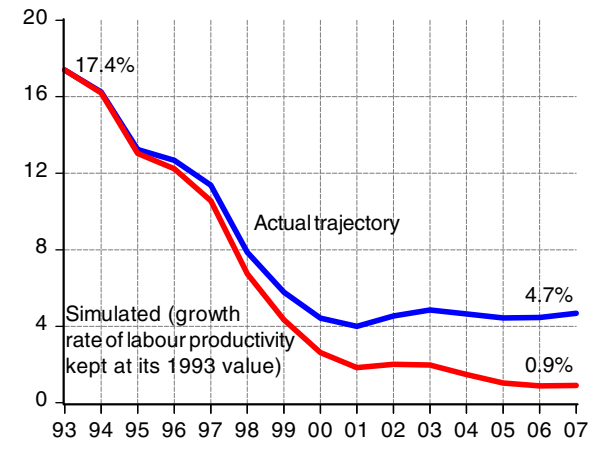

\section{e. Both variables, Spain}

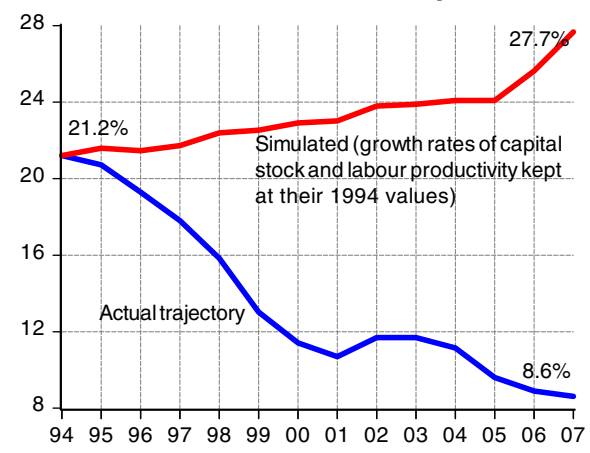

\section{f. Both variables, Ireland}

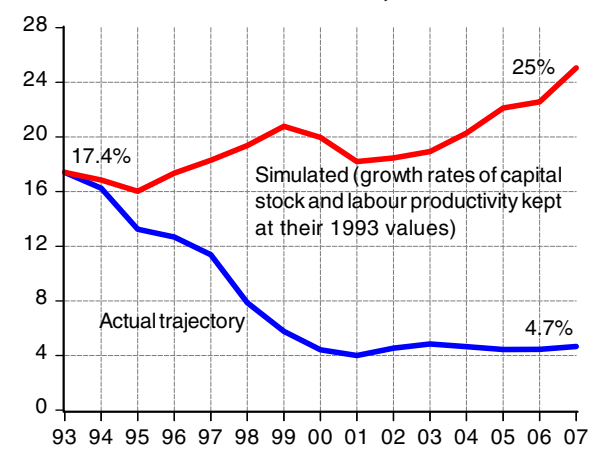

Figure 4 Unemployment rate: Contribution of growth variables, pre-2007. 
Another variable of concern, especially when it comes to discussing the current extent of the welfare state in developed economies, is the social security benefits paid by governments (as percent of GDP). As can be seen from Table 9, both countries experienced a reduction in their welfare entitlement programmes that has clearly contributed to reduce unemployment levels (see Benito and Hernando 2008, and Karanassou and Sala 2009, for Spain, and Grubb et al. 2009, for Ireland). According to our simulations, the contribution for Spain is as twice as large as the one for Ireland: -4.1 and -1.9 percentage points, respectively (row labelled as 'Welfare' at the bottom of Table 9). Figure 5 shows the simulations of the unemployment rates fixing the social benefits at their start-of-the-sample values.

The next set of variables deserving examination has to do with demographics. Here we make use of two variables: one which is broadly descriptive of the people taking part of labour market relations -participation rates for Spain and total population for Ireland-, and the other, which refers to the important immigration flows to both economies in very recent years. For both countries the increase of participation rates or population has brought about large effects in terms of unemployment. Here, contributions stand, respectively, at 9.1 and 7.9 percentage points for Spain and Ireland. After taking account of immigration, the total contribution of demographics still remains of rather similar magnitude in the two countries (see the row 'Demographics' in Table 9). Unfortunately, it is not possible at this point to produce an intuitive graphical comparison. ${ }^{23}$

Finally, some other variables that enter our models are private consumption, foreign demand, and the real interest rate for Spain, and indirect taxes for Ireland. Fiscal reforms, low interest rates and rising real wages are behind the marked increased in Spanish private consumption (see, for example, Karanassou and Sala 2009, and Eurofound 2010). The sharp contraction of Spain's foreign demand can be ascribed to the loss of competitiveness after the entrance into the European Monetary Union (1999). That, and the huge misallocation of resources that followed, seem to have had a serious effect in terms of unemployment (6.7 percentage points). ${ }^{24}$ In contrast, the European Central Bank's relaxed monetary policy contributed to reducing Spain's unemployment (by 2 percentage points), although arguably at the cost of a generalised bubble-like expansion -primarily focused on the construction sector- which is underway for the last couple of decades (see Eironline 2008, and Eurofound 2010).

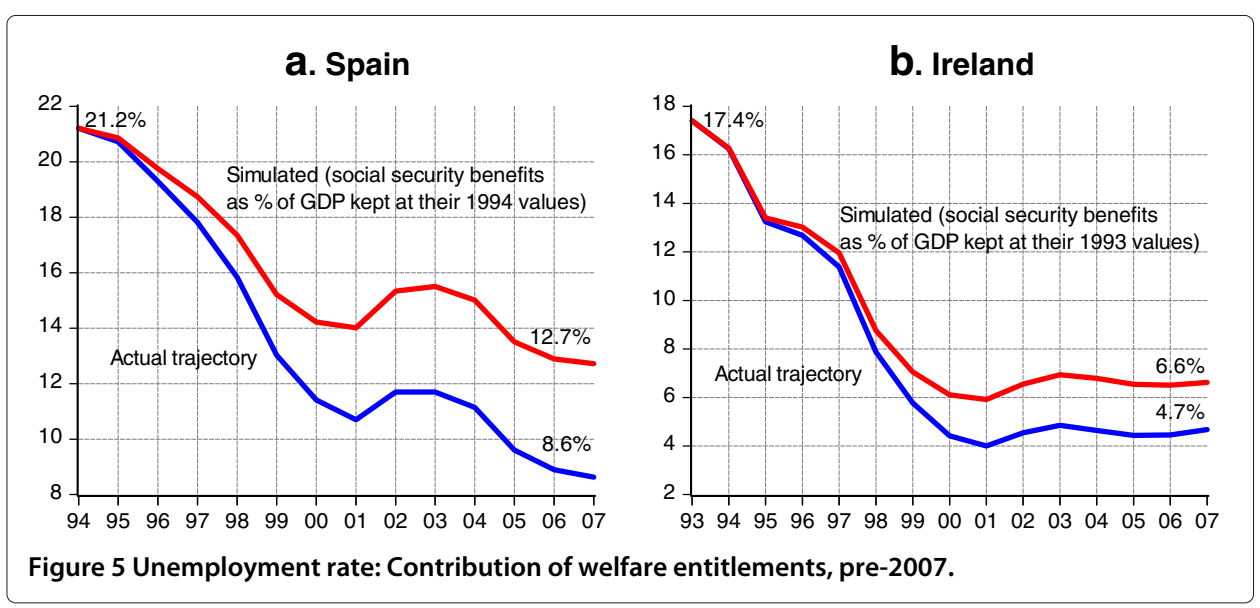




\subsection{Post-2007 analysis}

We now shift our attention to the events that marked the evolution of the unemployment trajectories in Spain and Ireland during the post-2007 years. In spite of the sample's short length for this second dynamic accounting exercise, we still believe that it can be revealing when it comes to retrieving the differences and similarities between the two countries. Again, we are able to identify two common features for our joint simulations in Figures 6a and 6b: (i) the steep rise of both unemployment rates (blue lines) in the lapse of a very few years - more than two-fold for Spain and almost three-fold for Ireland-; and (ii) the relevance of all exogenous variables in explaining the whole of the change in unemployment (the outcome is not as good as before for Spain though). The short span of 2007-2009 is certainly in stark contrast to the preceding years of high labour market performance in both countries under scrutiny. ${ }^{25}$

Table 10 goes over the individual and joint contributions for this period and, just as before, arranges them into groups as to allow for comparisons more directly. Notice on the first row that the Spanish unemployment went up by 11.3 percentage points, whereas the Irish unemployment rate increased by 7.8 percentage points.

As in the previous analysis, the growth in the capital stock is to be seen as the major force behind the changes in the unemployment rates (see, among others, Karanassou et al. 2008, Bande and Karanassou 2009, and Karanassou and Sala 2009). This time, however, because of the drop in the variable the effect on unemployment is just the opposite. Once again, the individual contribution of capital accumulation for Ireland more than doubles the one found for Spain in absolute values: 13.4 and 4.7 percentage points, respectively. The contributions of the growth rate of productivity are this time trivial (for the joint contribution of capital and productivity see the row labelled as 'Growth' at the bottom of Table 10).

Figure 7 shows the individual and joint contributions of the growth variables for 2007-2009. Here we can see, very clearly, the differences in the contributions of capital accumulation for both countries (Figures 7a and 7b), the non-significant effect of productivity rates in both cases (Figures $7 \mathrm{c}$ and $7 \mathrm{~d}$ ), and the joint contribution of growth variables (Figures $7 \mathrm{e}$ and $7 \mathrm{f}$ ). Notice how the unemployment rate would have reached a near-zero value in Ireland had capital stock kept accruing at the higher rate of 2007 (Figures 7b and $7 f$ ).
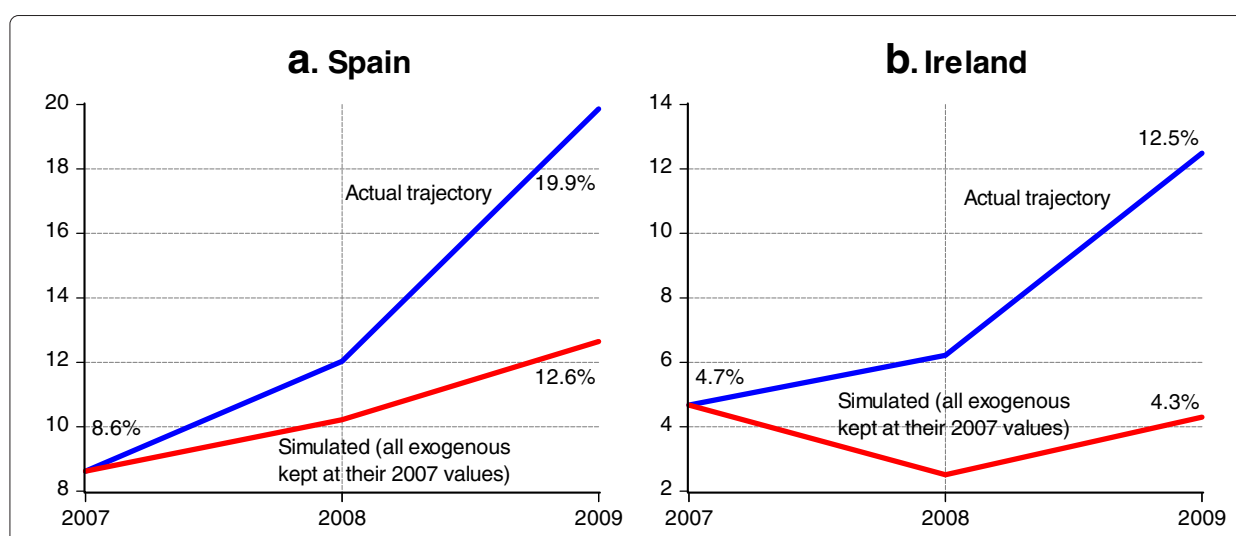

Figure 6 Unemployment rate: Joint dynamic contributions, post-2007. 
Table 10 Changes in variables and contributions, post-2007

\begin{tabular}{|c|c|c|c|c|c|c|c|c|c|}
\hline & \multicolumn{3}{|c|}{ Actual values: } & \multirow{2}{*}{$\begin{array}{c}\text { cont.: } \\
\Delta u^{\dagger}\end{array}$} & & \multicolumn{3}{|c|}{ Actual values: } & \multirow{2}{*}{$\begin{array}{l}\text { cont.: } \\
\Delta \boldsymbol{u}^{\dagger}\end{array}$} \\
\hline & 2007 & $2009^{*}$ & $\Delta^{\dagger}$ & & & 2007 & $2009^{*}$ & $\boldsymbol{\Delta}^{\dagger}$ & \\
\hline Spain: & & & & & Ireland: & & & & \\
\hline u & 8.6 & 19.9 & 11.3 & - & u & 4.7 & 12.5 & 7.8 & - \\
\hline$\Delta k$ & 6.2 & 5.0 & -1.2 & 4.7 & $\Delta k$ & 6.6 & 2.9 & -3.7 & 13.4 \\
\hline$\Delta p r$ & 0.5 & 1.7 & 1.2 & 0.2 & $\Delta p r$ & 2.3 & 0.5 & -1.8 & -0.4 \\
\hline$b$ & 11.6 & 14.6 & 3.0 & 1.0 & $b$ & 10.3 & 15.3 & 5.0 & 0.9 \\
\hline$z$ & 73.1 & 74.5 & 1.4 & 0.5 & $\Delta p o$ & 2.4 & 1.6 & -0.8 & -1.1 \\
\hline$d^{00}$ & 1 & 0 & - & -0.1 & $d^{96}$ & 1 & 0 & - & -2.6 \\
\hline c & 60.3 & 58.7 & -1.6 & 2.2 & $\tau^{i}$ & 13.3 & 11.0 & -2.3 & -2.1 \\
\hline$f d$ & -10.4 & -5.3 & 5.1 & -1.6 & & & & & \\
\hline \multirow[t]{6}{*}{ r } & 1.1 & 3.8 & 2.7 & 0.3 & & & & & \\
\hline & & contril & tions: & 7.2 & & & contrib & tions: & 8.2 \\
\hline & & & Growth: & 4.9 & & & & frowth: & 13.0 \\
\hline & & & Welfare: & 1.0 & & & & Velfare: & 0.9 \\
\hline & & Demc & raphics: & 0.4 & & & Demo & aphics: & -3.7 \\
\hline & & & Other: & 0.9 & & & & Other: & -2.1 \\
\hline
\end{tabular}

As a direct consequence of the 2007 crisis welfare entitlements showed a tendency to rise in most developed countries. Spain and Ireland were certainly no exceptions (see Grubb et al. 2009, the OECD Economic Survey 2009a, for Ireland, and the OECD Economic Outlook 2010c, for Spain and Ireland). As expected, the effects on unemployment levels went now in the other direction and were of very similar magnitudes (see also the row 'Welfare' at the bottom of Table 10). Figure 8 provides the graphical comparison.

Beyond the effects of the crisis on decreasing capital accumulation and the enlargement of the welfare state, we ought to consider now the change on the dynamics of demographics and its contribution to unemployment. Here, our quantitative variables - participation rates and total population - show a modest (Spain) or negative (Ireland) change during this period. The total effects are now rather different. Whereas the contribution for Spain is positive and small ( 0.4 percentage points), for Ireland is negative and significantly larger (-3.7 percentage points).

Finally, the crisis has brought private consumption down in Spain, which is reflected in a contribution of 2.2 percentage points to unemployment (see Eurofound 2010). However, this effect has been somehow compensated by an increase of foreign demand, which reduced unemployment by 1.6 percentage points. On Ireland, it should be noted the important easing effect the reduction in indirect taxes has brought into the economy, which accounted for a drop in the unemployment rate of the order of 2.1 percentage points.

\section{Conclusions}

In this paper we present dynamic labour market models for Spain and Ireland. Following the Chain Reaction Theory (CRT) of unemployment we estimate a labour demand, labour supply, and wage setting equation model for each country. We then centre our attention on the main determinants of unemployment before and after the recent crisis of 2007, and discover some common characteristics of both labour markets. 


\section{a. Capital stock, Spain}

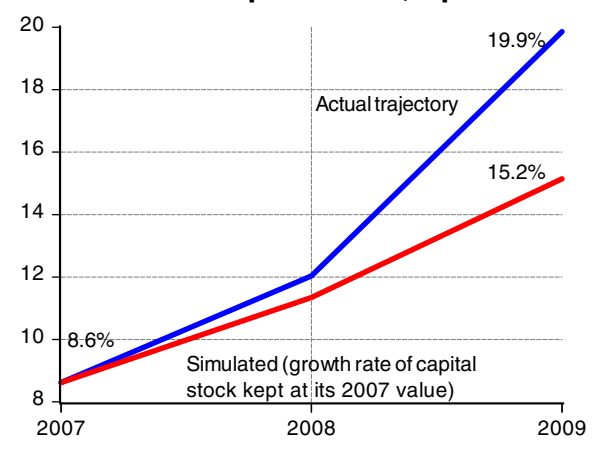

C. Labour productivity, Spain

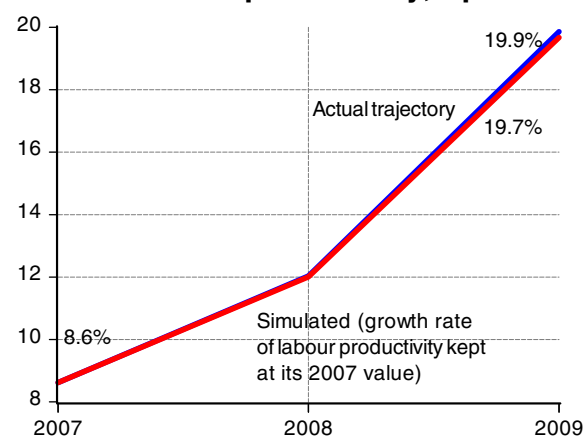

e. Both variables, Spain

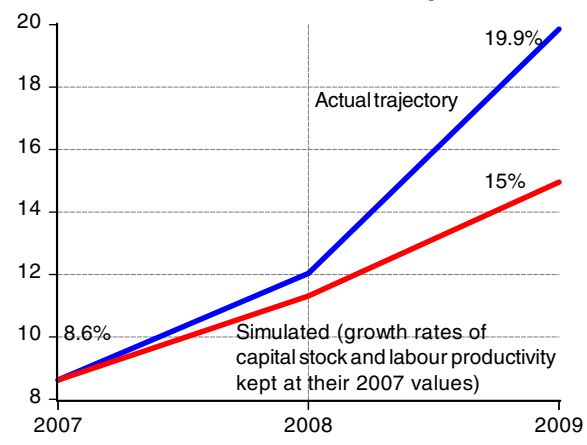

\section{b. Capital stock, Ireland}

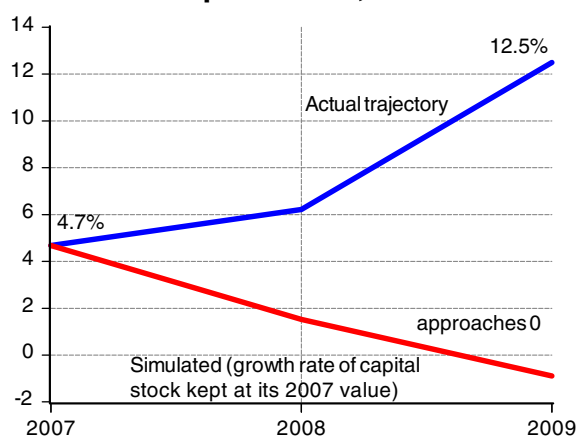

d. Labour productivity, Ireland

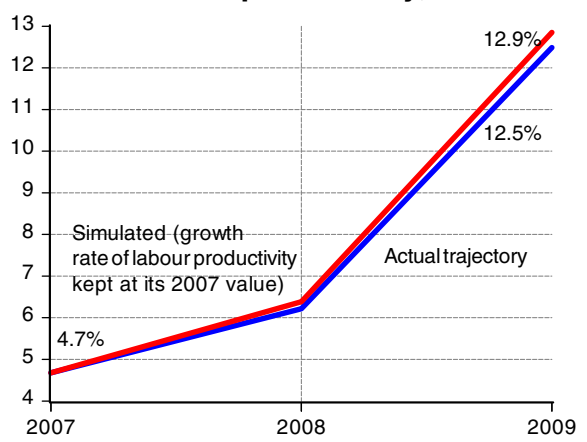

f. Both variables, Ireland

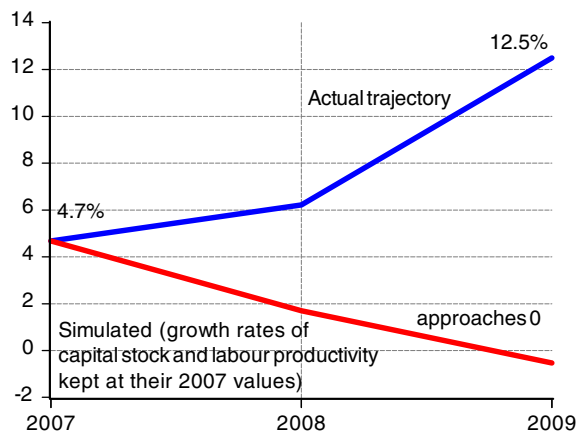

Figure 7 Unemployment rate: Contribution of growth variables, post-2007.

Our estimates show that the high growth rates of capital stock during the 1990s contributed to the significant decline in unemployment in Spain and Ireland. Inversely, the lower rates of capital accumulation in 2008 and 2009 led to the steep rise of the unemployment rates in both countries. In particular, the total individual contribution of capital stock in Ireland more than doubles that of Spain. To a lesser extent, other common drivers of unemployment are labour productivity, demographics, and social benefits. Moreover, some idiosyncratic variables -private consumption, foreign demand, and the interest rate in Spain, and indirect taxes in Ireland- are found to influence the trajectory of the unemployment rates to some degree.

Our results suggest some common ground for policy measures. Due to the central role played by the growing variables in our analysis, we should stress those policies related to 
a. Spain

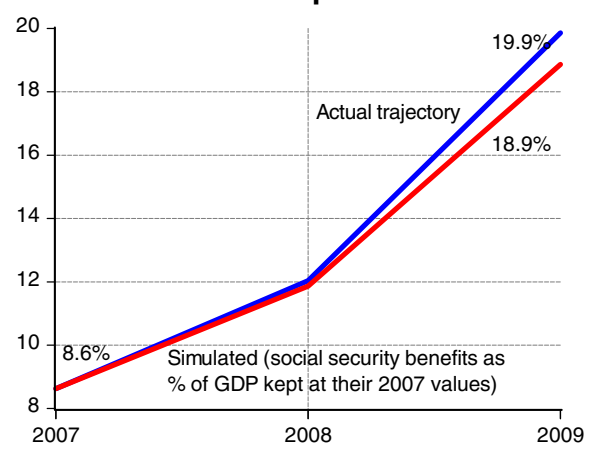

b. Ireland

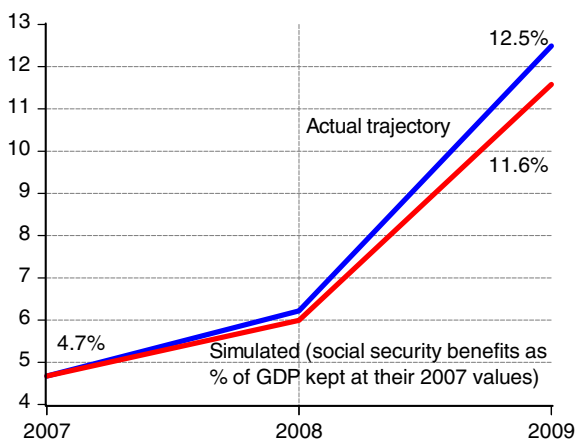

Figure 8 Unemployment rate: Contribution of welfare entitlements, post-2007.

promote R\&D activities and innovation and to foster investment. These "growth" policies should be accompanied by a gradual reduction of the welfare benefits that act as a real disincentive to work. This feature clearly sets the CRT apart from other more conventional approaches (e.g. NRU-NAIRU) which have so far put the stress on labour market flexibility, in general, and welfare entitlements in particular, as the major hindering forces preventing good labour market performance. We have shown in this paper that this is but a small part of the story.

\section{Endnotes}

${ }^{1}$ Notice that throughout the paper we will employ data up to 2009. We are aware of the drawback that this represents but, unfortunately, we are compelled to it due to the changes that have affected the structure of the OECD Economic Outlook Database -our major source of information for the empirical analysis below.

${ }^{2}$ Spanish unemployment went down from a peak of 21.2 percent in 1994 to a trough of 8.6 percent in 2007, while Irish unemployment dropped from 17.4 percent in 1993 to 4.7 percent in 2007.

${ }^{3}$ According to OECD (2010b), the overall index on the strictness of employment protection legislation between the mid-1990s and 2007 is (on average) 1.1 for Ireland and 3.0 for Spain. In addition, the Heritage Foundation 2011 publishes an index on economic freedom featuring Spain and Ireland's labour markets as, respectively, "repressed to mostly unfree" and "mostly free to free", over the period 2005-2011 (http://www.heritage.org/ Index/).

${ }^{4}$ For recent studies focusing on the relationship between the impact of the global financial crisis and labour market flexibility see, Bernal-Verdugo et al. (2012), Artha and de Haan (2011), Eichhorst and Marx (2011), and Eichhorst et al. (2010), among others.

${ }^{5}$ All three approaches provide different conceptions of the labour market. The main distinction comes from how they treat the short- and long-run states of the labour market. The NRU decomposes unemployment into "structural" and "cyclical" unemployment and cyclical unemployment variations are independent of structural variations. The hysteresis hypothesis does not distinguish between long-run equilibrium and cyclical variations and all cyclical variations are structural (all temporary shocks have permanent unemployment effects). The CRT, in turn, assumes that short, medium, and long runs are interrelated; 
that is, cyclical unemployment variations can have prolonged after-effects (see Karanassou et al. 2007).

${ }^{6}$ All these adjustment costs are well documented in the literature. See, for example, Nickell (1978), Sargent (1978), Taylor (1979), Lindbeck and Snower (1987), and Layard and Bean (1989).

7 The model (1)-(3) is compatible with standard microeconomic foundations (as in Karanassou et al. 2007).

${ }^{8}$ We should note that the results are robust to the bandwidth value of the kernel density estimation. The details of this analysis are available on request and are based on the estimation of the model (1)-(3), which we undertake in the next section. For a more technical discussion on kernel density functions and their application to this context see Karanassou et al. (2008).

${ }^{9}$ We have also experimented with other exogenous variables -social security contributions, measures of competitiveness, financial wealth, and real money balances- but these were found to have no explanatory power.

${ }^{10}$ The dynamic system (6) is stable if, for given values of the exogenous variables, all the roots of the determinantal equation

$$
\left|\mathbf{A}_{0}-\mathbf{A}_{1} B-\mathbf{A}_{2} B^{2}\right|=0
$$

lie outside the unit circle. Note that the estimated equations given below satisfy this condition.

${ }^{11}$ Tables 4, 5 and 6 below only give the 3SLS results, while the OLS estimates are available upon request.

12 Labour market flexibility goes beyond the speed of adjustment of labour demand to shocks. Just remember that, as per our model, other channels do exist -that of real wages and the labour force. In fact, Ireland's own flexibility is ranked $9^{\text {th }}$ in the world (see World Competitiveness Yearbook 2010). See also Kiander and Virén (2001) and Rodgers (2007) for different measures of flexibility, and the OECD report (2010b) for an overall index on the strictness of employment protection legislation.

${ }^{13}$ In Ireland, the variable takes the value 1 in the period 1996-2008, representing the extraordinary reversal of the migratory flows in this country in the last years. The marked inflows began in the mid-1990s and accelerated in 2004 with the enlargement of the EU; however, in 2009 the net migratory flows became negative (see, for example, Barrett 2009; Barrett and Kelly 2012, and OECD 2006). In the case of Spain the variable takes the value 1 in the period 2000-2008, when this economy experienced an immigration boom that lasted until 2008. In 2009, Spain has seen a large decrease of net migration. Since the end of 2008, the Spanish government has implemented a series of measures to revert the migratory inflows (e.g. in September 2008 it introduced a voluntary return programme for non-EU migrants, the Royal Decree 4/2008 of 19 September). Although there is not yet a clear evidence of the impact of these measures, there is some support that immigrants are leaving Spain (see, for example, Leschke and Watt 2010 and OECD 2009a).

14 The Spanish labour force series comes from the OECD Economic Outlook 87, but only for years 1977-2009. To stretch the series back to 1967 we rely on the AMECO (2010) database of the European Commission; we use the growth rate of the AMECO series into the original OECD series for 1967-1976.

15 The sample, too, is somewhat larger in this case, and covers some of the years under 
Franco's dictatorship. That explains the unusually and deceptive low unemployment rates experienced up until Franco's death (1975), as seen in most of the centrally-planned economies of the world -both right and left. Despite this issue, our counterfactual experiments below are robust to the re-estimation of the model using a restricted sample for the democracy period (1976-2009 instead of 1967-2009).

${ }^{16}$ At this stage we only consider the $I(1)$ variables in our models: $n_{t}, w_{t}, l_{t}, k_{t}, p r_{t}$, and $p o_{t}$. For the sake of exposition unit root tests are not reported (but are available on request).

17 Spanish and Irish unemployment rates started to climb, respectively, in May and August 2007 (see Eurostat 2011).

${ }^{18}$ Some examples can be found in Henry et al. (2000) for the UK, Agnese and Sala (2009) for Japan, Karanassou and Sala (2009) for Spain, Karanassou and Sala (2010) for Australia, and Pehkonen et al. (2011) for Finland and Sweden.

19 See, for instance, Estrada et al. (2009), Karanasou and Sala (2009), and Bentolila et al. (2010), for Spain, and Fitzgerald and Hore (2002), Sexton (2002), and Barrett et al. (2011), for Ireland. See also the OECD Economic Surveys for Spain (2007) and Ireland (2006).

${ }^{20}$ Bande and Karanassou (2009) and Karanassou and Sala (2009) also find that capital accumulation is the most important determinant of Spanish unemployment, while Pehkonen et al. (2011) obtain this same result for two Nordic countries, Finland and Sweden.

${ }^{21}$ Strong multicollinearity would prevent us to introduce the labour productivity variable into the labour demand equations due to the presence of capital stock.

${ }^{22}$ A further exercise, which is left for future research, concerns the endogenisation of labour productivity by way of adding a production function into the systems above. Remember here that we define labour productivity as the ratio of output to labour input. ${ }^{23}$ The unemployment rate would approach zero much too early in the simulation for Ireland (year 2000), and it would indeed be negative for the following years up to 2007 (the ending point of the simulation).

${ }^{24}$ According to Karanassou and Sala (2009), had foreign demand remained at its 1994 value, Spanish unemployment would have been 5.8 percentage points higher in 2007.

25 See especially Bentolila et al. (2010), and Bergin et al. (2010). The reader is also referred to Eichhorst et al. (2010) for Spain, and the OECD Economic Surveys for Spain $(2008,2010 a)$ and Ireland (2009a).

\section{Additional file}

Additional file 1: Appendix A. Actual and simulated trajectories of the exogenous variables.

Competing interests

The IZA Journal of European Labor Studies is committed to the IZA Guiding Principles of Research Integrity. The authors declare that they observed these principles.

Acknowledgements

We are thankful to the participants of both the Spanish SAE (Malaga, December 2011) and the II Workshop in Time Series Econometrics (Zaragoza, April 2012) for all comments and suggestions. All errors remain our own.

Responsible editor: Alan Barrett

Author details

${ }^{1}$ FH Düsseldorf and IZA , Department of Business Studies, Universität Straße, Gebäude 23.32, 40225 Düsseldorf, Germany. ${ }^{2}$ CONICET and Universidad Nacional de Cuyo, Facultad de Ciencias Económicas, Centro Universitario M5502JMA Mendoza, Argentina. 
Received: 10 November 2012 Accepted: 19 December 2012 Published: 31 December 2012

\section{References}

Agnese P, Sala H (2009) The fading 1990s in Japan: driving forces behind the unemployment upsurge. Int Rev Econ Finance 18(3): 428-439

AMECO Database EuropeanCommission, Economic and Financial Affairs. European Monetary Union (1999). http://ec. europa.eu/economy_finance/ameco/

Artha IKDS, de Haan J (2011) Labor market flexibility and the impact of the financial crisis. Kyklos 64: 213-230

Bande R, Karanassou M (2009) Labour market flexibility and regional unemployment rate dynamics: Spain 1980-1995. Papers Reg Sci 88(1): 181-207

Bande, R, Karanassou M (2010) Spanish regional unemployment revisited: the role of capital accumulation. IZA Discussion Paper No. 5012

Bande R, Fernández M, Montuenga M (2008) Regional unemployment in Spain: disparities, business cycle and wage setting. Labour Econ 15(5): 885-114

Barrett A (2009) EU enlargement and Ireland's labour market. In: Kahanec M, Zimmermann, KF (eds) EU labor markets after post-enlargement migration. Springer, Berlin, pp 145-161

Barrett A, Bergin A (2009) Estimating the impact of immigration in Ireland. Nordic J Pol Econ 35(2)

Barrett A, Kelly E (2012) The Impact of Ireland's Recession on the Labour Market Outcomes of its Immigrants. Eur J Popul 28(1)

Barrett A, Fitzgerald J, Nolan B (2002) Earning inequality, returns to education and immigration into Ireland. Labour Econ 9(5): 665-680

Barrett A, Bergin A, Duffy D (2006) The labour market characteristics and labour market impacts of immigrants in Ireland. Econ Soc Rev 37(1): 1-26

Barrett A, Bergin A, Kelly E (2011) Estimating the impact of immigration on wages in Ireland. Econ Soc Rev 42(1): 1-26

Benito A, Hernando I (2008) Labour demand, flexible contracts and financial factors: new evidence from Spain. Oxford Bull Econ Stat 70(3): 283-301

Bentolila S, Jimeno JF (2006) Spanish unemployment: the end of the wild ride? In: Werding, M (ed) Structural unemployment in Western Europe, Reasons and Remedies. MIT Press, Cambridge MA, London UK, pp 2006

Bentolila S, Saint-Paul G (1992) The macroeconomic impact of flexible labor contracts with an application to Spain. Eur Econ Rev 36(5): 1013-1047

Bentolila S, Cahuc P, Dolado JJ, Le Barbanchon T (2010) Two-tier labor markets in the great recession: France vs. Spain. IZA Discussion Paper No. 5340

Bernal-Verdugo L, Furceri D, Guillaume D (2012) Labor market flexibility and unemployment: new empirical evidence of static and dynamic effects. Comp Econ Stud 54(2): 251-273

Bergin A, Conefrey T, Fitzgerald J, Kearney I (2010) Fiscal policy for recovery: the case of Ireland. EUROFRAME Conference, Amsterdam, 11th June 2010

Blanchard O, Wolfers J (2002) The role of shocks and institutions in the rise of European unemployment: the aggregate evidence. Econ J 110(462): C1—C33

Borjas GJ (2003) The labor demand curve is downward sloping: re-examining the impact of immigration on the labor market. Q J Econ 118(4): 1335-1374

Carrasco R, Jimeno J, Ortega A (2008) The effect of immigration on the labor market performance of native-born workers: some evidence for Spain. J Popul Econ 21(3): 627-648

Decoster A, Loughrey J, O'Donoghue C, Verwerft D (2009) Incidence and welfare effects of indirect taxes, European measures of income and poverty: lessons for the U.S. - International Policy Exchange Series

Dolado J, Jimeno JF (1997) The causes of Spanish unemployment: a structural VAR approach. Eur Econ Rev 41(7): 1281-1307

Eichhorst W, Marx P (2011) Reforming German labour market institutions: a dual path to flexibility. J Eur Soc Policy 21 (1): 73-87

Eichhorst W, Feil M, Marx P (2010) Crisis, what crisis? Patterns of adaptation in European labor markets. Appl Econ Q Suppl 56(61): 29-64

Eironline (2008) Sharp downturn in construction sector (Juan Arasanz Díaz, 11.14.2008). http://www.eurofound.europa. eu/eiro/2008/10/articles/es0810039i.htm

Estrada Á, Jimeno JF, Malo de Molina JL (2009) The Spanish economy in EMU: the first ten years. Documentos Ocasionales No. 0901, Banco de España

Eurofound (2010) Spain: a country profile, Eurofound. http://www.eurofound.europa.eu/pubdocs/2010/08/en/1/ EF1008EN.pdf

Eurostat (2011) Impact of the economic crisis on unemployment, statistics explained (2011/5/4). http://epp.eurostat.ec. europa.eu/statistics_explained/index.php/Impact_of_the_economic_crisis_on_unemployment

Fitzgerald J, Hore J (2002) Wage determination in economies in transition: Ireland, Spain and Portugal. ESRI Working Paper No. 147

Garriga C (2010) The role of construction in the housing boom and bust in Spain. FEDEA Working Papers 2010-09

González L, Ortega F (2011) How do very open economies adjust to large immigration flows? Evidence from Spanish regions. Labour Econ 18(1): 57-70

Gordon R (1997) The time-varying NAIRU and its implications for economic policy. J Econ Perspect 11(1): 11-32

Görg H, Henry M, Strobl E, Walsh F (2009) Multinational companies, backward linkages, and labour demand elasticities. Can J Econ 42(1): 332-348

Grubb D, Singh S, Tergeist P (2009) Activation Policies in Ireland. OECD Social, Employment and Migration Working Papers No. 75, OECD Publishing. doi:10.1787/227626803333

Henry B, Karanassou M, Snower DJ (2000) Adjustment dynamics and the natural rate: an account of UK unemployment. Oxf Econ Pap 52(1): 178-203 
Johansen S (1988) Statistical analysis of Cointegrating vectors. J Econ Dyn Control 12: 231-254

Johansen, S (1992) Determination of Cointegration rank in the presence of a linear trend. Oxf Bull Econ Stat 54(3): 383-397 Johansen, S (1995) Likelihood-based inference in Cointegrated vector auto-regressive Models. Oxford University Press, Oxford

Karanassou M, Sala H (2009) The rise and fall of Spanish unemployment: a chain reaction theory perspective In: Arestis P, Sawyer, M (eds) International Papers in Political Economy, Palgrave-Macmillan

Karanassou, M, Sala H (2010) The wage-productivity gap revisited: is the labour share neutral to employment? IZA Discussion Paper No. 5092

Karanassou M, Snower DJ (1997) Is the natural rate a reference point? Eur Econ Rev 41: 559-569

Karanassou, M, Snower DJ (1998) How labour market flexibility affects unemployment: long-term implications of the chain reaction theory. Econ J 108: 832-849

Karanassou M, Sala H, Salvador PF (2008) Capital accumulation and unemployment: new insights on the nordic experience. Camb J Econ 32(6): 977-1001

Karanassou M, Sala H, Snower DJ (2007) The macroeconomics of the labor market: three fundamental views. Port Econ J 6(3): 151-180

Kiander J, Virén M (2001) Measuring labour market flexibility in the OECD Countries. Empirica 28: 187-201

Layard R, Bean C (1989) Why does unemployment persist? Scand J Econ 91 (2): 371-396

Leschke J, Watt A (2010) How do institutions affect the labour market adjustment to the economic crisis in different EU countries?. ETUI Working Paper 2010.04, Brussels

Lindbeck A, Snower DJ (1987) Union activity, unemployment persistence, and wage-employment ratchets. Eur Econ Rev 31(1-2): 157-167

Nickell S (1978) Fixed costs, employment and labour demand over the cycle. Economica 45(180): 329-345

OECD (2006) OECD economic surveys: Ireland. OECD, Paris

OECD (2007) OECD economic surveys: Spain. OECD, Paris

OECD (2008) OECD economic surveys: Spain. OECD, Paris

OECD (2009a) OECD economic surveys: Ireland. OECD, Paris

OECD (2010a) OECD economic surveys: Spain. OECD, Paris

OECD (2010b) Employment protection legislation: strictness of employment protection legislation: Overall, OECD employment and labour market statistics (database). doi:10.1787/data-00317-en

OECD (2010c) Economic Outlook No. 87 (June 2010)

Palma ML, Martín JL (2010) Globalization and migration flows. Some effects of immigration on the Spanish labour market in the last decade. Analele Stiintifice ale Universitatii "Alexandru loan Cuza" din lasi - Stiinte Economice 2010SE:273-290

Pantula SG (1989) Testing for unit roots in time series data. Econometric Theory 5(2): 256-271

Pesaran MH (1997) The role of economic theory in modelling the long-run. Econ J 107(440): 178-191

Pesaran MH, Shin Y (1999) An autoregressive distributed-lag modelling approach to Cointegration analysis In: Strom S (ed) Econometrics and economic theory in the Twentieth Century: The Ragnar Frisch Centennial Symposium, 371-413. Cambridge University Press, Cambridge

Pesaran MH, Shin Y, Smith RJ (2001) Bounds testing approaches to the analysis of level relationships. J Appl Econometrics 16(3): 289-326

Pehkonen J, Sala H, Salvador PF (2011) The nordic experience revisited: labour market booms and slumps since the 1990s in Finland and Sweden. J Econ Stud 38(1): 52-65

Rodgers G (2007) Labour market flexibility and decent work. DESA Working Paper No. 47

Sargent T (1978) Estimation of dynamic labor demand schedules under rational expectations. J Pol Econ 86(6): 1009-1044

Sexton JJ (2002) Interpreting recent developments in the economy and labour market. ESRI Q Econ Comment: Spec Articles 2002(1-Spring): 1-13

Taylor J (1979) Staggered wage setting in a macro model. Am Econ Rev 69(2): 108-113

The Heritage Foundation (2011). http://www.heritage.org/Index/

Walsh B (2006) Labour market adjustment in the Irish regions, 1988-2005. ESRI Q Econ Comment 2006(3-Autumn): 80-99 World Competitiveness Yearbook (2010). https://www.worldcompetitiveness.com/OnLine/App/Index.htm

doi:10.1186/2193-9012-1-9

Cite this article as: Agnese and Salvador: More alike than different: the Spanish and Irish labour markets before and after the crisis. IZA Journal of European Labor Studies 2012 1:9. 